\title{
Potentials and limitations of microorganisms as renal failure biotherapeutics
}

\author{
This article was published in the following Dove Press journal: \\ Biologics: Targets \& Therapy \\ 14 May 2009 \\ Number of times this article has been viewed
}

Poonam Jain

Sapna Shah

Razek Coussa

Satya Prakash

Biomedical Technology and Cell

Therapy Research Laboratory,

Department of Biomedical

Engineering and Physiology, Artificial

Cells and Organs Research Centre,

Faculty of Medicine, McGill University,

Montreal, Québec, Canada
Correspondence: Satya Prakash Biomedical Technology and Cell Therapy Research Laboratory, Department of Biomedical Engineering, Faculty of Medicine, McGill University, 3775 University Street, Montreal, Québec,

H3A 2B4, Canada

Fax +| $5|4398746|$

Email satya.prakash@mcgill.ca
Abstract: Renal insufficiency leads to uremia, a complicated syndrome. It thus becomes vital to reduce waste metabolites and regulate water and electrolytes in kidney failure. The most common treatment of this disease is either dialysis or transplantation. Although these treatments are very effective, they are extremely costly. Recently artificial cells, microencapsulated live bacterial cells, and other cells have been studied to manage renal failure metabolic wastes. The procedure for microencapsulation of biologically active material is well documented and offers many biomedical applications. Microencapsulated bacteria have been documented to efficiently remove urea and several uremic markers such as ammonia, creatinine, uric acid, phosphate, potassium, magnesium, sodium, and chloride. These bacteria also have further potential as biotherapeutic agents because they can be engineered to remove selected unwanted waste. This application has enormous potential for removal of waste metabolites and electrolytes in renal failure as well as other diseases such as liver failure, phenylketonuria, and Crohn's disease, to name a few. This paper discusses the various options available to date to manage renal failure metabolites and focuses on the potential of using encapsulated live cells as biotherapeutic agents to control renal failure waste metabolites and electrolytes.

Keywords: renal failure, microencapsulation, artificial cells, oral administration, bacterial cells, metabolites, electrolytes, polymeric membrane

\section{Renal failure, waste metabolites, and electrolytes}

Kidney disease is among the most common diseases afflicting over 20 million Americans. Over 90,000 fatalities occur every year due to kidney diseases. Nearly 350,000 Americans suffer from end-stage renal disease (ESRD), the final stage in chronic renal failure. Each year, the number of patients with chronic kidney failure increases by an astounding $11 \%$ !

Kidney malfunction results from a reduction in glomerular filtration rate and causes an increase in concentration of waste metabolites that are measurable in blood. ${ }^{1}$ For example, in human waste, metabolites such as blood urea nitrogen (BUN) increase from $15 \mathrm{mg} / \mathrm{dl}$ to $100-300 \mathrm{mg} / \mathrm{dl}$, serum creatinine increase from $1 \mathrm{mg} / \mathrm{dl}$ to $10-25 \mathrm{mg} / \mathrm{dl}$, and considerable amounts of uric acid are also known to accumulate. ${ }^{2-4}$ More specifically, in uremia, the concentration of uremic toxins such as ammonia, urea, phenols, indoles, and guanidino compounds such as N-methyl guanidine (NMG) and guanidino succinic acid (GSA) are significantly altered with accompanying abnormalities in acid-base equilibrium, and retention of electrolytes and water retention. 5 ,6 The accumulation of uremic toxins in patients suffering from renal insufficiency inhibits various physiologic and biochemical functions thereby manifesting 
toxic symptoms. For example, hyperammonium can lead to mental retardation and, in severe cases, coma. ${ }^{7}$ Water retention causes edema and as the concentration of hydrogen ions increases, acidosis develops. If untreated, acidosis and uremia can cause coma and eventually result in death. Thus, the high concentrations of these substances in have to be lowered before their increased level results in severe disturbances of metabolic pathways. Thus, as the kidney is accountable for the elimination of wastes from the blood, any damage, either from an accident or disease that causes renal insufficiency in the patient, can lead to a build-up of toxic waste in the body. Removing urea and ammonia from the plasma is not only necessary in kidney failure, ${ }^{1,8-11}$ but also in other diseases like liver failure. , $8,12,13^{2}$

\section{Treatment options for managing renal failure waste metabolites and electrolytes}

Effective treatments for renal failure and elucidation of uremia have traditionally been dialysis or a kidney transplant. Only $15 \%$ of the world's uremic patients can afford dialysis treatment, as it is a very expensive, time-consuming, and complicated technique. ${ }^{4,14-16}$ About 80,000 Americans on dialysis die of various complications each year. As a result of the global shortage of kidney donors for kidney transplants, high costs linked with transplant surgery, and high probability of organ rejection, most patients worldwide have very few options for effective treatment after kidney failure. Over 27,000 patients are on waiting lists for kidney transplants each year and only about 11,000 receive transplants. There is great urgency in the quest for an unconventional, affordable therapy for patients who cannot afford expensive dialysis or kidney transplant to keep them alive. Medical scientists are attempting to research and develop an innovative, low expense therapy that goes beyond the traditional treatment for reinstated kidney function. Several alternatives have been considered. ${ }^{4,9,10,17-23}$

In the past few decades, molecular technology has greatly influenced the course of biomedical research. Prospective medical applications include discovering the genetic basis for certain ailments, gene therapy, and production of effectual therapeutic agents. A distinguished researcher, Dr Kolff, found that creatinine, uric acid, and other nitrogenous wastes can easily be removed from plasma with oral sorbents. ${ }^{20}$ With the use of oral absorbents, the interval between hemodialysis treatments could be delayed considerably. ${ }^{21}$ Some researchers have proposed and confirmed the use of the co-immobilized enzyme, urease, which breaks down urea into ammonia which is then eliminated by adsorbents. ${ }^{9,10,17,18}$ However, some scientists report that the currently available ammonia adsorbent does not have adequate adsorbent capacity. ${ }^{16,19}$

An alternative approach has been suggested that would be cheaper and more convenient for the patient: an oral therapy containing a combination of adsorbents, osmotic agents, and ion-exchange agents. ${ }^{24}$ Chang examined the potential of combining a microencapsulated enzyme, urease, with an ammonium ion adsorbent, zirconium phosphate, to remove urea in vitro. Urease broke down urea to ammonium ions which were then adsorbed onto zirconium phosphate. This system had the ability to delay the onset of dialysis therapy in patients with partial kidney function and may even decrease the treatment times for dialysis in some patients. ${ }^{25}$ Oxystarch and urease-zirconium phosphate have been demonstrated to be successful in removing urea and ammonia., ${ }^{2,4}$ However, the amount required is too large to allow for use in routine treatment of the patients. ${ }^{26}$ and also markedly small amount of urea removal have been reported in vivo, particularly at a neutral $\mathrm{pH} .^{6,13,15,19,23,27-30}$

In another approach, a microencapsulated multienzyme system that converts urea and ammonia into essential amino acids was investigated. ${ }^{13,18,19,28}$ However, this encapsulated multienzyme system had an inadequate urea and ammonia conversion rate. ${ }^{31}$ Thus, the desire for an efficient system for urea and ammonia removal is apparent. ${ }^{32}$ It is essential to develop novel approaches to replace kidney function that majority of the world can afford. One prospect involves creation of a 'bioartificial/bionic kidney' in which normal renal function are performed by tissue culture cells implanted in a hollow fiber or mesh matrix. ${ }^{33}$ In spite of great potential for the bionic kidney, it, too, will be exorbitantly expensive and will require extremely skilled personnel. In a recent article in the April 2007 issue of The FASEB Journal, Cody Mooneyhan described the use of puffer fish gills to excrete ammonia at the molecular level using Rh proteins and reported that the protein which excretes ammonia through puffer fish gills was found to be similar to human Rh blood proteins. Thus, by targeting human Rh proteins, people with damaged livers and kidneys can eliminate toxic ammonia from their bloodstream. ${ }^{34}$

Stem cells are unspecialized precursor cells that can self-renew and develop into specialized cells. Stem cell researchers are working towards the ultimate goal of production of a new kidney as a mean of kidney therapy. This is a complicated challenge since the kidney is made from several specialized cell types, each with its own 
unique function. Another strand of biotechnology that holds promise in the treatment of kidney failure is the use of bioencapsulated living cells. ${ }^{35}$ It is possible to genetically engineer nonpathogenic bacterial cells for a desired metabolic activity and they then serve as outstanding therapeutic agents. The idea of administering encapsulated bacterial enzymes to break down toxic substances was first introduced in Finland in $1978 .{ }^{32,36}$ In one proposed system, selected bacteria converted nitrogeneous waste products into nontoxic chemicals that could be recycled within the subject. ${ }^{24,37}$ Thus, several approaches to treat renal insufficiency have been proposed. ${ }^{4,13,15,16,23,29,30,38-40}$ Some researchers suggest the use of microencapsulated urease to convert urea into ammonia that is subsequently removed by coencapsulated ammonia adsorbent ${ }^{9,14}$ or as mentioned above, some researchers propose administering microencapsulated multienzyme complex to convert urea and ammonia into essential amino acids ${ }^{9,15,39,28}$ or using lyophilized urea-utilizing soil bacteria. ${ }^{41,42}$

Microencapsulated cells have also been reported to be successful in other medical complications. For example, the microencapsulated islet cells were found to remain viable and secreted insulin to regulate glucose levels in diabetic rats. This approach prevented immunorejection after implantation. ${ }^{43}$ Similarly, microencapsulated hepatocytes have been shown to lower the high serum bilirubin level to $6.00 \pm 1.00 \mathrm{mg} / 100 \mathrm{~mL}$ twenty days after implantation in Gunn rats. Analysis showed that this was achieved because the implanted encapsulated hepatocytes carried out the function of the liver in the conjugation of bilirubin ${ }^{44,45}$ and enhanced the survival time of fulminant hepatic failure in rats. ${ }^{45}$ Recent reports by another group also support this finding. ${ }^{46}$ The possibility of using live selected bacteria, preferably Bacillus pasteurii or Lactobacillus sporogenes, in vivo to treat renal, hepatic and gastrointestinal diseases by eliminating toxins and other metabolic waste products has been proposed. ${ }^{7}$ The study also showed that a probiotic containing either B. pasteurii and L. sporogenes, or both, are capable of increasing survival in otherwise untreated uremic rats.

In another approach to alleviate uremia or renal insufficiency, a mixture comprising of one or more selected bacteria (which converts nitrogenous waste into nontoxic compounds in vivo), along with one or more of the following: a prebiotic, ammoniaphilic bacteria with high urease activity, and/or sorbents with specific adsorption affinities for uremic toxins and inorganic phosphate along with a water sorbent have been proposed. ${ }^{43} \mathrm{~A}$ series of probiotics (foods that contain 'beneficial' bacteria, such as Lactobacillus), along with oral adsorbents like charcoal and locust bean gum, have also been explored and tested in subjects as a potential oral renal replacement therapy. ${ }^{47}$

There have been rapid advances in molecular biology that have resulted in the use of genetically engineered microorganisms for remedial purposes. Genetically engineered cells that were incapable of surviving passage through the gastrointestinal tract have made it successfully to their destination by the use of artificial cell microcapsules. Microorganisms can be engineered to remove unwanted molecules from the body as they travel through the intestine and are finally excreted in the stool without being retained in the body. This idea has great prospects and it is likely that soon trained bacteria will act as a substitute for the kidney and liver and perform most endocrine functions.

Microencapsulated genetically modified cells have been reported to have enormous potential for the elimination of certain metabolites such as urea in kidney failure, ammonia in liver failure, and amino acids such as phenylalanine in phenylketonuria and other innate errors of metabolism..$^{48}$ In addition, genetically engineered encapsulated Erwinia herbicola cells have demonstrated an ability to convert ammonia into usable amino acids for the cells before being eliminated via the bowel. Microencapsulated genetically engineered Escherichia coli DH5 cells have also been shown to be effective in removal of urea and ammonia in an in vitro system and in a uremic rat animal model ${ }^{49,50}$ Despite the research in this field, we are still looking for a suitable urea and ammonia removal system. The most promising approach, using microencapsulated bacterial cells for renal therapy, is discussed extensively in this article.

\section{Potential of live free and encapsulated cells in renal failure}

About forty years ago, Malchesky first suggested that certain natural strains of microorganisms were exceptionally successful in degrading urea in vitro. He also reported that these microbes can be trained to enhance their ability to degrade urea and other compounds normally excreted in urine..$^{51}$ Soon after, Setala pioneered the notion of oral delivery of lyophilized bacteria harvested from soil. ${ }^{36}$ These bacteria were extremely effective in degrading nonprotein nitrogenous compounds in uremic patients.

Later, in the 1990s, Chang established the concept of delivery of microencapsulated genetically modified bacteria to 
degrade nitrogenous waste products in uremic patients in vivo as well as in vitro. The procedures for microencapsulation of biologically active materials are well recognized and offer various biomedical applications. ${ }^{9,11,13,17,22,31,52-54}$ Thus, the possibility of using bacterial cells to treat kidney failure has been explored for over four decades. Research in the field of artificial cell microcapsules revealed the possibility of oral administration of live genetically engineered cells for therapeutic functions. ${ }^{32,55}$ This concept has direct relevance for the use of encapsulated bacterial oral therapy in renal failure and liver failure, ${ }^{32}$ physiologically responsive gene therapy, ${ }^{56,57}$ and somatic gene therapy. ${ }^{58,59}$ Modern technological advances in molecular biology have resulted in the accessibility of nonpathogenic genetically engineered microorganisms that can effectively use uremic metabolites for cell growth. This paper is an overview of the options available to overcome renal sufficiency. One of the options discussed extensively is the current research on using microencapsulated bacterial cells such as $E$. coli DH5 to degrade waste metabolites such as urea, uric acid, and creatinine among others, as an improved therapy of renal failure. The results obtained upon oral administration of microencapsulated bacterial cells to degrade such waste metabolites in uremia are summarized here.

\section{Potential of encapsulated cells in renal failure urea removal}

Renal insufficiency results in an elevated plasma urea level. Several approaches have been suggested to degrade plasma urea. In the 1980s, the novel approach of using encapsulated bacteria was shown to be 10 times more efficient in degrading urea than oxystarch. One gram of oxystarch was found to adsorb only $103.00 \mathrm{mg}$ of urea at $\mathrm{pH} 7.4$ at a urea concentration of $0.02 \mathrm{M} .^{5}$ Thus, to eliminate $40 \mathrm{~g}$ of urea from $40 \mathrm{~L}$ fluid (100 mg/dL urea), $388.34 \mathrm{~g}$ of oxystarch was required. Microencapsulated genetically engineered bacteria were reported to be 30 times more efficient compared to microencapsulated enzyme urease-zirconium phosphate. The encapsulated urease-zirconium-phosphate system only eliminated $1.60 \mathrm{mg}$ of urea nitrogen or $33.00 \mathrm{mg}$ urea/g of microcapsules. ${ }^{5}$ Therefore, massive quantities of microcapsules containing this system were needed to successfully remove $40 \mathrm{~g}$ of urea from the body.

Certain bacterial cells are reported to be very effective in lowering BUN levels in vivo. When partially nephrectomized rats were orally given $B$. pasteurii and L. sporogenes, the BUN levels were lowered to $62.0 \pm 21$ and
$63.0 \pm 26 \mathrm{mg} / \mathrm{dl}$, respectively compared to a previous concentration of $99.0 \pm 46 \mathrm{mg} / \mathrm{dl}$. This reduction of $38 \%$ and $37 \%$, respectively indicated that $B$. pasteurii and L. sporogenes administered orally as dietary supplements could metabolize urea in vitro. ${ }^{7}$

Alternatively, the use of probiotics in removal of plasma urea has also been explored. Suspension of L. delbrueckii in uremic plasma reduced the urea nitrogen levels from $51.5 \pm 5.2 \mathrm{mg} / \mathrm{dL}$ to $44.3 \pm 3.9 \mathrm{mg} / \mathrm{dL}(\mathrm{p}=0.02)$ after 24 hours in vitro. With microencapsulation of Lactobacillus (inside semipermeable alginate-polylysine-alginate polymeric membrane [APA]), further lowering of urea nitrogen levels was achieved $(35.4 \pm 0.8 \mathrm{mg} / \mathrm{dL}, \mathrm{p}=0.03)$ at 24 hours. It is proposed that expression of certain enzymes could be induced in $L$. delbrueckii which can then effectively lower plasma urea $^{60}$ and possibly other waste metabolites in uremia.

Recently, Chang and Prakash proposed the use of microencapsulated genetically engineered bacterial cells to remove plasma urea and ammonia. In vitro, $40.00 \pm 8.60 \mathrm{~g}$ of APA-encapsulated bacteria were shown to remove $87.89 \pm 2.25 \%$ of the plasma urea within 20 minutes and $99.99 \%$ of urea in 30 minutes. Bacterial cells were reported to use urea for their metabolic nitrogen requirement and did not produce ammonia as a by-product. ${ }^{57}$ Thus, results demonstrate that this biotechnological approach is 10-30 times more competent in eliminating urea and ammonia than the currently available traditional approaches. ${ }^{31}$

In a different study, surgical renal failure induced in rats (removal of one kidney and the partial ligation of the other) resulted in a substantial increase in blood urea levels without noticeable disturbances in water and electrolyte balances. A drop in the plasma urea level from $52.08 \% \pm 2.06 \% \mathrm{mg}$ to $9.10 \% \pm 0.71 \% \mathrm{mg}$ was observed upon daily oral administration of log phase microencapsulated genetically engineered $E$. coli DH5 cells for 21 days. The plasma urea level was maintained within the normal range during the entire treatment period. The urea levels became elevated once the treatment was stopped. ${ }^{61,62}$ It is hypothesized that during the passage of microcapsules through the gastrointestinal tract, small molecules from the body, such as urea, ammonia, amino acids, etc., diffuse into the microcapsules where they are metabolized by genetically engineered cells for their nitrogen source before being excreted in the stool. This results in lowering the high plasma urea level to standard levels in uremic rats with induced kidney failure. ${ }^{32}$ Since urea levels returned to pretreatment values upon stopping the treatment, it is implied that there is no significant retention of $E$. coli $\mathrm{DH} 5$ cells in the intestine. ${ }^{63}$ 
One can argue about the potential toxicity due to the leakage of encapsulated cells during their passage through the intestinal tract. In the in vivo studies, the oral administration of both free and encapsulated bacteria to uremic rats lowered systemic urea from the initial 52.08 $(\mathrm{SD}=2.37) \mathrm{mg} / \mathrm{dl}$ to $10.58(\mathrm{SD}=0.85) \mathrm{mg} / \mathrm{dl}$. However, the free $E$. coli DH5 cells were found to be retained in the intestine and when the treatment ceased, the free bacteria were still able to lower systemic urea. ${ }^{62}$ Unlike free bacteria, microencapsulated bacteria were excreted in the stool. The results showed that, even if all the E. coli $\mathrm{DH} 5$ cells leaked out, there would be no negative effect on the growth and/or survival of the renal failure rats. ${ }^{64}$ It is reported that uremic rats survived longer when they received encapsulated $E$. coli DH5 cells. ${ }^{64,65}$

\section{Potential of encapsulated cells in renal failure ammonia removal}

The fate of ammonia during urea removal by daily administration of microencapsulated genetically engineered bacteria has also been examined. The blood ammonia levels that were always present in the range of $539 \pm 51 \mu \mathrm{M}$ decreased significantly to $144 \pm 24.70 \mu \mathrm{M} .{ }^{32}$ In vitro, $40.00 \pm 8.60 \mathrm{~g}$ of APA-encapsulated bacteria have been reported to lower ammonia from $975.14 \pm 70.15 \mu \mathrm{M} / \mathrm{L}$ to $81.151 \pm 7.37 \mu \mathrm{M} / \mathrm{L}$ in $30 \mathrm{~min} .{ }^{31}$ The most recent studies in uremic rats also showed a reduction of other waste metabolites such as, uric acid, creatinine, potassium, and phosphate..$^{55,66,67}$

\section{Potential of encapsulated cells in renal failure creatinine removal}

High level of plasma creatinine occurs in renal insufficiency, uremia, and other diseases. Serum creatinine levels were reported to be lowered in rats fed with $B$. pasteurii and L. sporogenes from $0.9 \pm 0.25 \mathrm{mg} / \mathrm{dl}$ and $0.9 \pm 0.2 \mathrm{mg} / \mathrm{dl}$, respectively compared to a previous concentration of $1.5 \pm 0.56 \mathrm{mg} / \mathrm{dl}$. A substantial reduction of approximately $40 \%$ in both groups was observed. These results indicate that B. pasteurii and L. sporogenes administered orally as dietary supplements metabolize creatinine in vitro. ${ }^{43}$

Daily administration of microencapsulated genetically engineered E. coli DH5 cells have resulted in lowering plasma creatinine in vitro and in vivo. Results demonstrated that these artificial cells were able to lower plasma creatinine in vitro from $21.80 \pm 1.10 \mathrm{mg} / \mathrm{dl}$ to $19.34 \pm 0.60 \mathrm{mg} / \mathrm{dl}$ in three hours. ${ }^{67}$ It would be interesting to see if the creatinine levels were elevated again upon cessation of the oral treatment.

\section{Potential of encapsulated cells in renal failure uric acid removal}

Increase in systemic uric acid occurs in renal insufficiency. Recently, a proposal was put forth to use artificial cells containing microencapsulated genetically engineered E. coli DH5 cells for lowering uric acid in vitro and in vivo. Results show that genetically engineered bacteria have the ability to significantly lower uric acid from $84.80 \pm 3.40 \mathrm{mg} / \mathrm{dl}$ to $9.32 \pm 0.05 \mathrm{mg} / \mathrm{dl}$ in vitro. They were also capable of lowering uric acid levels from the plasma of the experimental animals from the control levels of $71.00 \pm 27.49 \mathrm{mg} / \mathrm{dl}$ to $20.33 \pm 17.92 \mathrm{mg} / \mathrm{dl}$ in vivo. ${ }^{55}$ Continued daily oral administration reduced the plasma uric acid concentration to normal range in uremic rats during the entire test period. Its potential in the removal of uric acid may have significance in uremia.

\section{Potential of encapsulated cells in removal of other renal failure waste metabolites}

Lowering of plasma magnesium, phosphate, sodium, chloride, uric acid, cholesterol, and creatinine is essential in uremia and other diseases. ${ }^{5,68}$ Microencapsulated genetically engineered microorganisms have been prepared that can remove waste metabolites such as potassium, phosphate, magnesium, sodium, chloride, uric acids, cholesterol, creatinine, and bilirubin in vitro. This has a significant implication in the use of oral microencapsulated genetically engineered microorganisms in uremia. These artificial cells were effective in removing the majority of waste metabolites from the plasma as summarized in Table 1. Further studies will reveal whether administration of the microencapsulated $E$. coli cells will cause a similar reduction of the above mentioned electrolytes and waste metabolites in vivo. This has exciting implications for the use of genetically engineered cells in a number of medical applications. However, encapsulated E. coli DH5 cells could not efficiently remove creatinine from the plasma. After 24 hours of incubation with encapsulated bacteria, $83.31 \% \pm 2.40 \%$ plasma creatinine was found remaining. ${ }^{69}$

All of the uremic metabolites tested, urea, cholesterol, uric acid, potassium, phosphate, magnesium, chloride, sodium and to a certain extent creatinine, are lowered to within normal levels without elevation of ammonia. The effectiveness of this approach was explored by studying the survival and growth of the renal failure rats receiving microcapsules containing genetically engineered $E$. coli DH5 cells. In this respect, untreated uremic control animals 
Table I Removal of electrolytes by microencapsulated genetically engineered $\mathrm{E}$. coli DH5 cells in vitro ${ }^{69}$

\begin{tabular}{lll}
\hline Metabolites & Concentration at $\mathbf{0}$ hours & Concentration at 24 hours \\
\hline Potassium & $5.80 \pm 0.40 \mathrm{mEq} / \mathrm{l}$ & $3.50 \pm 0.03 \mathrm{mEq} / \mathrm{l}(\mathrm{p}<0.00 \mathrm{I})$ \\
Phosphate & $2.20 \pm 0.9 \mathrm{mg} / \mathrm{dl}$ & $1.49 \pm 0.03 \mathrm{mg} / \mathrm{dl}(\mathrm{p}<0.005)$ \\
Magnesium & $0.90 \pm 0.04 \mathrm{mg} / \mathrm{dl}$ & $0.66 \pm 0.09 \mathrm{mg} / \mathrm{dl}(\mathrm{p}<0.005)$ \\
Sodium & $172 \pm 11.00 \mathrm{mEq} / \mathrm{l}$ & $129 \pm 6.12 \mathrm{mEq} / \mathrm{l}(\mathrm{p}<0.00 \mathrm{I})$ \\
Chloride & $137 \pm 6.60 \mathrm{mEq} / \mathrm{l}$ & $107 \pm 2.00 \mathrm{mEq} / \mathrm{l}(\mathrm{p}<0.005)$ \\
Uric acid & $84.80 \pm 3.40 \mathrm{mg} / \mathrm{dl}$ & $8.80 \pm 3.12 \mathrm{mg} / \mathrm{dl}(\mathrm{p}<0.00 \mathrm{I})$ \\
Cholesterol & $1.86 \pm 0.10 \mathrm{mmol} / \mathrm{l}$ & $1.37 \pm 0.06 \mathrm{mmol} / \mathrm{l}(\mathrm{p}<0.005)$ \\
\hline
\end{tabular}

died during the study period of 21 days, whereas the treated animal continued to survive and grew at about the same rate as normal animals. ${ }^{64}$ Another alternative to the oral administration of microencapsulated genetically engineered cells has been proposed by some researchers: the long-term implantation of cells. This can be an effective therapy for various conditions but will take numerous years to perfect. In the meantime, several researchers are looking into other approaches for a more immediate clinical application. For example, Aebischer's group suggested the ingenious use of capillary fibers to encapsulate cells that has permitted his group to insert these subcutaneously into the cerebrospinal fluid on a short-term basis. ${ }^{70}$ The capsules can be replaced as needed, ${ }^{70}$ and, so far, no immunological sensitivity to the capsules is obvious. This approach evades the problems posed by permanent or long-term implantation of microcapsules. The oral administration of microencapsulated genetically engineered cells obviates the problems of implantation. However, it can be used only for diseases where waste metabolites can be eliminated from the gastrointestinal tract, such as in liver or kidney failure and in some innate errors of metabolism such as phenylketonurea. ${ }^{48}$ Evidently, the clinical use of microencapsulated genetically engineered cells could require a combination of different approaches, including implantation, subcutaneous insertion, and oral administration, to treat different conditions. ${ }^{63}$

Immobilized bacteria have demonstrated an unlimited capacity to deplete cholesterol levels in vitro. ${ }^{57}$ However, for practical applications, suitable bacteria with an enhanced ability to degrade cholesterol are desirable. There is a strong possibility that this method may become accessible in the near future with the help of genetic engineering. Research in other systems such as using bioencapsulated hepatocytes has shown promising results and demonstrated the feasibility of using this for cell therapy. ${ }^{57}$ Further enhancement in biocompatibility may allocate this approach to be used for cell and gene therapy in humans. This is becoming a progressively more viable prospect because of the increasing advancement in genetic engineering and molecular biology. There has been an extensive growth in technical research in molecular biology leading to the generation of many genetically engineered microorganisms with unique and exceptional abilities. Microorganisms have been easily manipulated to overproduce enzymes and peptides and some have been engineered to metabolize large amounts of unwanted metabolites.

Recently, Prakash and Chang ${ }^{31,32,71}$ have reported oral administration of microencapsulated genetically engineered E. coli cells containing the Klebsiella aerogenes urease gene that causes the overexpression of the urease enzyme efficiently removes urea from the reaction media. Microencapsulated genetically engineered $E$. coli cells have the competence of efficiently removing urea without any increase in the ammonia levels in the medium. ${ }^{69}$ Using a single pool model, $40 \mathrm{~g}$ of microencapsulated genetically engineered E. coli cells could lower urea in 40 liters of the body water from $100 \mathrm{mg} / \mathrm{dl}$ to $1.60 \mathrm{mg} / \mathrm{dl}$ within 30 minutes. Also, $40 \mathrm{~g}$ of this microorganism was shown to lower ammonia in 40 liters of body water from $758.00 \mu \mathrm{M} / 1$ to $90.42 \mu \mathrm{M} / 1$ in as little as 20 minutes. Extrapolated results imply that the ability of microencapsulated bacteria to degrade urea is adequate to eliminate urea during renal insufficiency. ${ }^{72}$ Analogous reductions in blood levels of other metabolites have also been reported, implying that the DH5 cells have the capacity to regularize levels of several elevated metabolites during renal failure..$^{32,58,73}$ Detailed studies have been done on the optimization of procedural parameters for encapsulation of bacterial cells in the APA membrane and the profiles of genetically engineered microencapsulated bacteria to effectively remove urea and ammonia and the efficacy of urea and ammonia removal in vitro. ${ }^{31}$ In addition to its potential use in uremia, the removal of waste metabolites such as urea, ammonia, uric acid, bilirubin, and others are also required in other medical conditions such as liver failure. ${ }^{43}$ 
Table 2 Potential of using cells as a mode of therapy for renal failure and other diseases

\begin{tabular}{|c|c|c|c|}
\hline $\begin{array}{l}\text { Renal failure markers and disease } \\
\text { conditions }\end{array}$ & Cell types & $\begin{array}{l}\text { Potential mode } \\
\text { of therapy }\end{array}$ & Reference \\
\hline \multirow[t]{9}{*}{ Urea in renal failure, amyotrophic lateral sclerosis } & Free live E. coli DH5 & Oral & 58,62 \\
\hline & $\begin{array}{l}\text { Microencapsulated genetically } \\
\text { engineered bacteria }\end{array}$ & Oral & $3 I, 49,57,63,66,71,73,74$ \\
\hline & Microencapsulated E. coli DH5 & Oral & 62 \\
\hline & $\begin{array}{l}\text { E. coli with Klebsiella aerogenes } \\
\text { expressing urease }\end{array}$ & Oral & 72 \\
\hline & Soil bacteria & Oral & $4 \mathrm{I}, 42$ \\
\hline & $\begin{array}{l}\text { Encapsulated genetically modified } \\
\text { xenogenic cells }\end{array}$ & Intrathecal delivery & 70 \\
\hline & $\begin{array}{l}\text { Selected probiotic (B. pasteurii, } \\
\text { L. sporogenes), ammoniaphilic bacteria }\end{array}$ & Oral & $7,43,50$ \\
\hline & $\begin{array}{l}\text { Probiotic microencapsulated } \\
\text { L. delbrueckii }\end{array}$ & Oral & 50,65 \\
\hline & $\begin{array}{l}\text { Microencapsulated multienzyme } \\
\text { complex }\end{array}$ & Oral & $9,15,28,39$ \\
\hline \multirow[t]{4}{*}{ Ammonia in renal failure and liver disease } & $\begin{array}{l}\text { Microencapsulated multienzyme } \\
\text { complex }\end{array}$ & Oral & $9,15,28,39$ \\
\hline & Soil bacteria & Oral & $4 I, 42$ \\
\hline & $\begin{array}{l}\text { Microencapsulated genetically } \\
\text { engineered bacteria }\end{array}$ & Oral & $31,32,43,49,50,57$ \\
\hline & Microencapsulated E. coli DH5 & Oral & 57,71 \\
\hline \multirow[t]{2}{*}{ Uric acid in renal failure } & $\begin{array}{l}\text { Microencapsulated genetically } \\
\text { engineered bacteria }\end{array}$ & Oral & $43,66,69,74$ \\
\hline & Microencapsulated E. coli DH5 & Oral & $55,66,67$ \\
\hline \multirow[t]{3}{*}{ Creatinine in renal failure and other diseases } & $\begin{array}{l}\text { Microencapsulated genetically } \\
\text { engineered bacteria }\end{array}$ & Oral & 66,69 \\
\hline & L. sporogenes, B. pasteurii & Oral & 43 \\
\hline & Microencapsulated E. coli DH5 & Oral & $55,66,67$ \\
\hline $\begin{array}{l}\text { Other metabolites; potassium/phosphate/ } \\
\text { magnesium/sodium/chloride in uremia and other } \\
\text { diseases }\end{array}$ & $\begin{array}{l}\text { Microencapsulated genetically } \\
\text { engineered microorganisms }\end{array}$ & Oral & 69 \\
\hline Nonprotein nitrogenous compounds in uremia & Lyophilized soil bacteria & Oral & $4 \mathrm{I}, 42$ \\
\hline Insulin in diabetes & Microencapsulated islet cells & Implantation & 43 \\
\hline \multirow[t]{2}{*}{ Serum bilirubin in fulminant hepatic failure rats } & Encapsulated hepatocytes & Implantation & $44-46$ \\
\hline & $\begin{array}{l}\text { Microencapsulated genetically } \\
\text { engineered microorganisms }\end{array}$ & Oral administration & $43,55,66,67,69$ \\
\hline $\begin{array}{l}\text { Toxins and other metabolic wastes in renal, hepatic } \\
\text { and gastrointestinal diseases }\end{array}$ & $\begin{array}{l}\text { Live selected bacteria: } B \text {. pasteurii } \\
\text { and } L \text {. sporogenes }\end{array}$ & Oral administration & 7 \\
\hline
\end{tabular}

O'Loughlin and colleagues have recently undertaken a study to demonstrate the competence of a combination of genetically engineered bacteria to lower elevated levels of metabolites such as urea and uric acid. Two strains of genetically modified bacteria, one expressing enzyme 'urease' to degrade urea and the other expressing enzyme 'uricase' to degrade uric acid, were prepared, combined and encapsulated in APA microcapsules for oral administration. Within 24 hours, $5 \mathrm{~mL}$ of these capsules were capable of successfully eliminating $95 \%$ of the urea and over $99 \%$ of the uric acid in vitro from a $100 \mathrm{~mL}$ solution formulated to mimic the concentration of these solutes in a hemodialysis patient. ${ }^{74}$ This approach could potentially serve in conjunction to maintenance dialysis in patients with chronic renal failure. However, reduction of urea concentration in vivo required coadministration of an ion-exchange resin to adsorb ammonia. Reduction of uric acid concentration in vivo was very efficient and did not require the administering 
of ion-exchange resin. Oral delivery of a combination of genetically engineered bacterial cells should be further investigated as a valuable accessory to dialysis and/or to immunosorption for the treatment of uremia $^{74}$ in chronic kidney failure models.

O'Loughlin and colleagues pioneered the approach of using a combination of enzymes in a single delivery vehicle to degrade multiple uremic toxins in a nonbacterial system. An alginate microcapsule was developed that contained three enzymes, urease, uricase, and creatininase, which are capable of effectively degrading urea, uric acid, and creatinine, respectively, and are significantly elevated in patients with renal insufficiency. The microcapsules were evaluated both in vitro and in vivo in a rodent model. In vitro, $5 \mathrm{~mL}$ of the capsules equipped with a few milligrams of the enzymes within 24 hours effectively degraded $100 \%$ of the uric acid, $97 \%$ of the urea, and $70 \%$ of the creatinine in a $100 \mathrm{~mL}$ formulated solution that mimicked the concentration of these solutes in uremic plasma. In vivo experiments involved a chemically induced acute renal failure rat model to evaluate the ability of encapsulated enzymes along with an oral sorbent (ion-exchange resin) to degrade uremic toxins. ${ }^{75}$ This approach has the potential to be extended to a bacterial system and has considerable prospect of being to be used in conjunction therapy in the treatment of ESRD.

\section{Oral administration of encapsulated cells live cells as potential renal failure kidney substitute}

It has recently been demonstrated that daily oral administration of artificial cells microcapsule containing a genetically engineered microorganism has potential as a renal failure kidney substitute. Furthermore, these genetically modified bacteria also have the ability to remove potassium, phosphate, uric acid, and other waste metabolites from uremic plasma. Future research may lead to the efficient and effective use of microencapsulated genetically modified bacteria as therapeutic agents. ${ }^{58}$

The accessibility of an oral bacterial therapy has the potential to save over 400,000 lives worldwide each year. Research has demonstrated that these microencapsulated genetically engineered bacteria are much more successful in removing ammonia than any method currently available..$^{31,32,75}$ If further detailed investigation convinces us about the efficacy and safety of this approach for urea removal, it might be possible to use this technology to remove waste metabolites such as urea, ammonia, creatinine, and uric acid in uremic patients with chronic renal failure. Because of these encouraging results, further research will concentrate on experimental design to use the concept of oral administration of genetically engineered bacterial cells in combination with other technologies for in vivo use. Thus, this approach will complete the currently available oral therapy for uremia using adsorbents, ion-exchange resins, and osmotic agents. The oral administration approach might therefore also be applicable for the removal of ammonia in other diseases such as chronic liver failure.

The use of microencapsulated bacterial cells has potential application not only in renal insufficiency, innate errors of urea metabolism, but also in liver insufficiency and gastrointestinal disorders and diseases. ${ }^{43}$ The feasibility of oral administration of polymeric artificial cells containing genetically engineered cells for the specific removal of undesirable amino acids in some innate errors of metabolism as in phenylketonurea ${ }^{48}$ has been reported. Further detailed studies on efficacy and safety are required before this promising new approach can be fully recognized and applied.

Microencapsulated genetically modified cells can be administered orally to a subject with uremia to alleviate the symptoms of uremia. Depending on the extent of renal damage in the patient suffering from uremia, with this oral therapy the patient either will not require dialysis, require dialysis less frequently, and for shorter periods, or maybe will not require initiation of dialysis as early as would be needed without treatment. In initial stages of ESRD, before fluid retention, genetically modified bacterial cells can be administered orally alone. However, in later stages with fluid retention in patients, the oral approach could be combined with minute quantities of an oral osmotic agent such as mannitol, ${ }^{24}$ to remove about a liter of fluid per day. Recent demonstrations have implied that daily dialysis avoids large fluctuations in the systemic waste metabolites. This oral approach could be used as in combination with standard dialysis to prevent large fluctuations in the systemic waste metabolites. The swift and proficient removal of uric acid may have added potential applications in hyperuricemia, such as in gout and in chemotherapy. ${ }^{66}$ Future studies will unveil the potential use of encapsulated genetically engineered bacteria for removal of urea and ammonia in biotechnology, chemical engineering, and biomedical applications. ${ }^{31}$

Will a combination of microencapsulated E. coli DH5 cells to deplete urea, and oral adsorbents and osmotic agents to regulate water, electrolytes, and other uremic waste metabolites remove the need for dialysis entirely in patients with kidney failure ${ }^{63}$ Will the oral administration of these 
genetically modified bacterial cells to uremic patients result in decreased frequency of dialysis or perhaps even decreased dialysis treatment times ${ }^{51}$ Further research could conceivably produce an alternative treatment of chronic renal failure and provide an insight for the future direction of this emergent and highly prospective technology. This also has potential applications in cell and gene therapy. ${ }^{57}$

\section{Conclusion}

Kidney failure leads to uremia, a complicated syndrome associated with increased levels of unwanted metabolites and electrolytes. ${ }^{3-5}$ It becomes essential to remove waste metabolites and regulate water and electrolytes in patients with renal insufficiency. Standard treatment by dialysis or transplantation is very effective but is extremely expensive and unaffordable by the majority of the world. Researchers of other approaches including absorbents, are faced with one major challenge, the need to remove large amounts of urea, ammonia, and other waste metabolites and electrolytes. ${ }^{46,16,19,22,23,28,76}$ Currently, artificial cells are being investigated with great optimism for use in the replacement of cell and even organ functions, especially related to metabolic functions in the treatment of diseases such as diabetes, liver failure, and kidney failure. When artificial microencapsulated cells are given by implantation, ${ }^{13,36,77-80}$ The problem of retention in the body is eliminated due to the use of polymeric membranes. Orally administered microencapsulated live cells warrants investigation as a supplement to the routine dialysis system to avert large fluctuations in the systemic waste metabolites and electrolytes. Further detailed analysis, particularly on safety studies are vital. If proven safe, this approach of using microencapsulated live cells will be an economical means for managing renal failure redundant waste metabolites and electrolytes.

\section{Acknowledgments}

We gratefully acknowledge financial support from the Canadian Institutes of Health Research (CIHR) to SP. The authors also would like to acknowledge the generous contribution of the following colleagues, Christopher Martoni, Meenakshi Malhotra, and Jasmine Bhathena. The authors report no conflicts of interest in this work.

\section{References}

1. Charles S, David M, Stacia M, editors. Control of body fluid, electrolyte, and acid-base balance. In: Human Physiology: Foundations and Frontiers. St. Louis, MO: Times-Mirror College Publications. 1998: p. 526-527.

2. Ashaba H, Bergstrom J, Furst, Christina J, Yahiel V. Middle molecules in uremia and other diseases. 1980;137-141.
3. Cohen BD. Uremic toxins in uremia. In: Kulte R, Geoffrey B, Benjamin BC, editors. International Conference on Pathogenesis, Diagnosis and Therapy. 1972;1-11.

4. Kolff WJ. Artificial kidney and artificial heart: further considerations. Int J Artif Organs. 1990;13(7):404-406.

5. Esposito R, Carmelo G. Sorbents and their clinical applications. London, UK: Academic Press; 1980. p. 133-153.

6. Kjellstrand C, Borges H, Pru C, Gardner D, Fink D. On the clinical use of microencapsulated zirconium phosphate-urease for the treatment of chronic uremia. Trans Am Soc Artif Intern Organs. 1981;27:24-30.

7. Prakash S. Oral bacteriology compositions and methods. Washington, DC: US Government Patent \#7026160; 2006.

8. Castelman B, McNeely BU. Case records of the Massachusetts General Hospital. N Engl J Med. 1974;290(1):39-49.

9. Cattaneo MV, Chang TM. The potential of a microencapsulated ureasezeolite oral sorbent for the removal of urea in uremia. ASAIO Trans. 1991;37(2):80-87.

10. Chang TM. Semipermeable aqueous microcapsules ("artificial cells"): with emphasis on experiments in an extracorporeal shunt system. Trans Am Soc Artif Intern Organs. 1966;12:13-19.

11. Chang TM. Semipermeable microcapsules. Science. 1964;146: 524-525.

12. Chang TM. Biotechnological and medical applications based on immobilization of hepatocytes, microorganisms, or enzyme systems by microencapsulation in artificial cells. Ann N Y Acad Sci. 1990;613: $109-115$.

13. Chang TMS. Biotechnology of artificial cells including its application in artificial organs. In: The Principles, Applications and Regulations of Biotechnology in Industry, Agriculture and Medicine. New York, NY: Pergamon Press; 1985. p. 53-72.

14. Chang TMS. Artificial cells for artificial kidney, artificial liver and detoxification. In: Artificial Kidney, Artificial Liver and Artificial Cells. New York, NY: Plenum Press; 1978. p. 57-77.

15. Chang TMS, Malouf C, Ressurreccion E. Artificial cells containing multienzyme systems for the sequential conversion of urea into ammonia, glutamate, then alanine. Artif Organs. 1979;3(Suppl): 284-287.

16. Sparks RE. Review of gastrointestinal perfusion in the treatment of uremia. Clin Nephrol. 1979;11(2):81-85.

17. Chang TM. Medical applications of immobilized proteins, enzymes, and cells. Methods Enzymol. 1988;137:444-457.

18. Chang TMS. New approaches using immobilized enzymes for the removal of urea and ammonia. Enzyme Eng. 1980;5:225-229.

19. Gu KF, Chang TM. Conversion of alpha-ketoglutarate into L-glutamic acid with urea as ammonium source using multienzyme systems and dextran-NAD(+) immobilized by microencapsulation within artificial cells in a bioreactor. Biotechnol Bioeng. 1988;32(3):363-368.

20. Kolff WJ. Longitudinal perspectives on sorbents in uremia. Kidney Int Suppl. 1976;(7):S211-S214.

21. Sanaka T, Sugino N, Teraoka S, Ota K. Therapeutic effects of oral sorbent in undialyzed uremia. Am J Kidney Dis. 1988;12(2): 97-103.

22. Sparks RE, Mason NS, Meier PM, Samuels WE, Litt MH, Lindan O. Binders to remove uremic waste metabolites from the GI tract. Trans Am Soc Artif Intern Organs. 1972;18:458-464, 484.

23. Walker JM, Jacobson RL, Stephen WJ, Rose D. The Role of Adsorbents in the Wearable Artificial Kidney. London, UK: MacMillan Press; 1977. p. 137-149.

24. Friedman EA. Bowel as a kidney substitute in renal failure. Am J Kidney Dis. 1996;28(6):943-950.

25. Wolfe EA, Chang TM. Orally ingested microencapsulated urease and an adsorbent, zirconium phosphate, to remove urea in kidney failure. Int J Artif Organs. 1987;10(4):269-274.

26. Gruy-Kapral C, Emmett M, Santa Ana CA, Porter JL, Fordtran JS, Fine KD. Effect of single dose resin-cathartic therapy on serum potassium concentration in patients with end-stage renal disease. $J$ Am Soc Nephrol. 1998;9(10):1924-1930. 
27. Gardner DL, Kjellstrand CM, Hassler CR, Fink DJ, Emmerling DC. An orally administered microcapsule system for treating chronic renal failure patients. Appl Biochem Biotechnol. 1984;10:27-40.

28. Gu KF, Chang TM. Conversion of ammonia or urea into essential amino acids, L-leucine, L-valine, and L-isoleucine, using artificial cells containing an immobilized multienzyme system and dextran-NAD+ 2. Yeast alcohol dehydrogenase for coenzyme recycling. Biotechnol Appl Biochem. 1990;12(3):227-236.

29. Hughes R, Williams R. Clinical experience with charcoal and resin hemoperfusion. Semin Liver Dis. 1981;169-172.

30. Man NK, Drueke T, Becker A, Zingraff J, Jungers P, Funck-Brentano JL. Clinical use of oxystarch. Kidney Int Suppl. 1976;(7):S269-S272.

31. Prakash S, Chang TM. Preparation and in vitro analysis of microencapsulated genetically engineered $E$. coli $\mathrm{DH} 5$ cells for urea and ammonia removal. Biotechnol Bioeng. 1995;46(6):621-626.

32. Prakash S, Chang TM. Microencapsulated genetically engineered live E. coli $\mathrm{DH} 5$ cells administered orally to maintain normal plasma urea level in uremic rats. Nat Med. 1996;2(8):883-887.

33. Humes HD. Tissue engineering of the kidney. In: The Biomedical Engineering Handbook. Baton Rouge, FL: CRC Press; 1995. p. $1807-1824$.

34. Mooneyhan, C. Something fishy in human blood could save lives. 2007. Accessed on Mar 10, 2009. Available from: http://www.fasebj. org/Press_Room/April_07_2_Press_Release.pdf.

35. Chang TM. Artificial cells and bioencapsulation in bioartificial organs. Ann N Y Acad Sci. 1997;831:249-259.

36. Setala K, Heinonen H, Schreck-Purla I. Ingestion of lyophilized soil bacteria for alleviation of uremic symptoms. J Inst Res Comm Syst. $1973 ; 73$

37. Schloerb PR. The management of uremia by perfusion of an isolated jejunal segment: with observations of the dynamics of water and electrolyte exchange in the human jejunum. J Clin Invest. 1958;37(12):1818-1835.

38. Chang TM. Removal of endogenous and exogenous toxins by a microencapsulated absorbent. Can J Physiol Pharmacol. 1969;47(12):1043-1045.

39. Chang TMS. Artificial Cells. Springfield, IL: Thomas; 1972.

40. Juggi JS. Extracorporeal cation-exchange circuits in the treatment of hyperammonaemia of hepatic failure. Med J Aust. 1973; 1(19):926-930.

41. Giordano C, Esposito R, Pluvio M. Further studies with oxystarch. Kidney Int Suppl. 1976;(7):S266-S268.

42. Setala K, Heinonen H, Schreck-Purola I. Uraemic waste recovery. II. In vitro studies. Proc Eur Dial Transplant Assoc. 1972;9:514-520.

43. Chang TM. Artificial cells: 35 years. Artif Organs. 1992;16(1):8-12.

44. Bruni S, Chang TM. Encapsulated hepatocytes for controlling hyperbilirubinemia in Gunn rats. Int J Artif Organs. 1991;14(4):239-241.

45. Bruni S, Chang TM. Hepatocytes immobilised by microencapsulation in artificial cells: effects on hyperbilirubinemia in Gunn rats. Biomater Artif Cells Artif Organs. 1989;17(4):403-411.

46. Dixit V, Darvasi R, Arthur M, Brezina M, Lewin K, Gitnick G. Restoration of liver function in Gunn rats without immunosuppression using transplanted microencapsulated hepatocytes. Hepatology. 1990;12(6):1342-1349.

47. Wolf F, Friedman E. Bioartificial Kidneys: Potential Application in Renal Replacement. 2006. Accessed on Mar 10, 2009. Available from: http://www.thedoctorwillseeyounow.com/articles/other/biokid_35/.

48. Chang TM. Artificial cells with emphasis on bioencapsulation in biotechnology. Biotechnol Annu Rev. 1995;1:267-295.

49. Prakash S, Chang TMS. Kinetic studies of microecnapsulated genetically engineered $E$. coli cells containing $\mathrm{K}$. aerogenes gene for urea and ammonia removal. Biotechnol Bioeng. 1995;46:621-626.

50. Prakash S, Chang TMS. Prebiotic and probiotic compositions and methodsfor their use in gut-based therapies. Washington DC: US Government Patent \#6706287; 2004. p. 883-887.

51. Malchesky PS, Nose Y. Biological reactors for renal support. Trans Am Soc Artif Intern Organs. 1977;23:726-729.
52. Chang TMS. Artificial cell including blood substitutes and 111: from ideas to applications. Artif Cells Blood Substit Immobil Biotechnol. 1994;22(5):vii-xiv.

53. Chang TMS. Living cells and microorganism immobilized by microencapsulation inside artificial cells. In: Fundamentals of Animal Cell Encapsulation and Immobilization. New York, NY: CRC Press; 1992. p. $183-196$.

54. Goosen MF, O'Shea GM, Gharapetian HM, Chou S, Sun AM. Optimization of microencapsulation parameters: Semipermeable microcapsules as a bioartificial pancreas. Biotechnol Bioeng. 1985;27(2):146-150.

55. Prakash $\mathrm{S}$, Chang TM. In vitro and in vivo uric acid lowering by artificial cells containing microencapsulated genetically engineered $E$. coli $\mathrm{DH} 5$ cells. Int J Artif Organs. 2000;23(7):429-435.

56. Chang TM. Future prospects for artificial blood. Trends Biotechnol. 1999;17(2):61-67.

57. Chang TM, Prakash S. Artificial cells for bioencapsulation of cells and genetically engineered E. coli. For cell therapy, gene therapy, and removal of urea and ammonia. Methods Mol Biol. 1997;63:343-358.

58. Prakash S, Jones ML. Artificial cell therapy: New strategies for the therapeutic delivery of live bacteria. J Biomed Biotechnol. 2005;2005(1):44-56.

59. Ross CJ, Ralph M, Chang PL. Delivery of recombinant gene products to the central nervous system with nonautologous cells in alginate microcapsules. Hum Gene Ther. 1999;10(1):49-59.

60. Chow KM, Liu ZC, Prakash S, Chang TM. Free and microencapsulated Lactobacillus and effects of metabolic induction on urea removal. Artif Cells Blood Substit Immobil Biotechnol. 2003;31(4):425-434.

61. Chang TMS, Loa SK. Urea removal by urease and ammonia absorbents in the intestine. The Physiologist. 1970;13(3):70.

62. Prakash S, Chang TM. Microencapsulated genetically engineered E. coli DH5 cells for plasma urea and ammonia removal based on: 1. Column bioreactor and 2. Oral administration in uremic rats. Artif Cells Blood Substit Immobil Biotechnol. 1996;24(3):201-218.

63. Chang TM, Prakash S. Therapeutic uses of microencapsulated genetically engineered cells. Mol Med Today. 1998;4(5):221-227.

64. Prakash S, Chang TM. Growth and survival of renal failure rats that received oral microencapsulated genetically engineered $E$. coli DH5 cells for urea removal. Artif Cells Blood Substit Immobil Biotechnol. 1998;26(1):35-51.

65. Chang TM. Artificial cell biotechnology for medical applications. Blood Purif. 2000;18(2):91-96.

66. Chang TM. Present status of modified hemoglobin as blood substitutes and oral therapy for end stage renal failure using artificial cells containing genetically engineered cells. Ann N Y Acad Sci. 2001;944: 362-372.

67. Prakash S, Chang TM. Artificial cells microencapsulated genetically engineered $E$. coli DH5 cells for the lowering of plasma creatinine in vitro and in vivo. Artif Cells Blood Substit Immobil Biotechnol. 2000;28(5):397-408.

68. Friedman EA, Saltzman MJ, Beyer MM, Josephson AS. Combined oxystarch-charcoal trial in uremia: sorbent-induced reduction in serum cholesterol. Kidney Int Suppl. 1976; (7):S273-S276.

69. Prakash S, Chang TM. Artificial cell microcapsules containing genetically engineered $E$. coli $\mathrm{DH} 5$ cells for in vitro lowering of plasma potassium, phosphate, magnesium, sodium, chloride, uric acid, cholesterol, and creatinine: a preliminary report. Artif Cells Blood Substit Immobil Biotechnol. 1999;27(5-6):475-481.

70. Aebischer P, Schluep M, Deglon N, et al. Intrathecal delivery of CNTF using encapsulated genetically modified xenogeneic cells in amyotrophic lateral sclerosis patients. Nat Med. 1996;2(6):696-699.

71. Chang TMS, Prakash S. Methods in Molecular Biology: Recombinant Gene Expression Protocols. New Jersey, NJ: Humana Press; 1996. p. 343-357.

72. Prakash S, Chang TM. Genetically engineered E. coli cells containing $K$. aerogenes gene, microencapsulated in artificial cells for urea and ammonia removal. Biomater Artif Cells Immobilization Biotechnol. 1993;21(5):629-636. 
73. Chang TMS, Prakash S. Microencapsulated genetically engineered microrganisms for clinical application. Washington DC: US Government Patent \#6217859; 1997.

74. O'Loughlin JA, Bruder JM, Lysaght MJ. In vivo and in vitro degradation of urea and uric acid by encapsulated genetically modified microorganisms. Tissue Eng. 2004;10(9-10):1446-1455.

75. O’Loughlin JA, Bruder JM, Lysaght MJ. Degradation of low molecular weight uremic solutes by oral delivery of encapsulated enzymes. ASAIOJ. 2004;50(3):253-260.

76. Friedman EA. Future Treatment of Renal Failure: Strategy in renal failure. New York, NY: Wiley; 1978. p. 521-528.
77. Demetriou AA, Felcher A, Moscioni AD. Hepatocyte transplantation. A potential treatment for liver disease. Dig Dis Sci. 1991;36 (9):1320-1326.

78. Demetriou AA, Whiting JF, Feldman D, et al. Replacement of liver function in rats by transplantation of microcarrier-attached hepatocytes. Science. 1986;233(4769):1190-1192.

79. Goosen AM, Mattheus FA. Research on animal cell culture in microcapsules. Chem Eng Educ. 1988;22:196-200.

80. Saavedra MJ, Baumann N, Oung I, Perman J, Yolken RH. Feeding of Bifidobacterium bifidum and Streptococcus thermophilus to infants in hospital for prevention of diarrhea and shedding of rotavirus. Lancet. 1995;344:1046-1049.

\section{Publish your work in this journal}

Biologics: Targets \& Therapy is an international, peer-reviewed journal focusing on the patho-physiological rationale for and clinical application of Biologic agents in the management of autoimmune diseases, cancers or other pathologies where a molecular target can be identified. This journal is indexed on PubMed Central, CAS,

\section{Dovepress}

EMBase, Scopus and the Elsevier Bibliographic databases. The manuscript management system is completely online and includes a very quick and fair peer-review system, which is all easy to use. Visit http://www.dovepress.com/testimonials.php to read real quotes from published authors.

Submit your manuscript here: http://www.dovepress.com/biologics-targets--therapy-journal 